\title{
Chapter 11 \\ Migration of Ukrainian Nationals to Portugal: The Visibility of a New Migration Landscape
}

\author{
Maria Lucinda Fonseca and Sónia Pereira
}

\subsection{Introduction}

Immigration from Ukraine to Portugal began at the end of the 1990s with a sudden migratory movement that generated one of the largest immigrant groups in Portugal. In 1996, only 71 Ukrainian citizens were registered in Portugal. By 2002 the number had risen to 62,448 . In 2014, Ukrainians were the third-largest foreign nationality in the country (after Brazil and Cape Verde). The magnitude of this sudden migration and the numeric relevance it gained as a foreign group in Portugal is unique within the migration of Ukrainians to other European countries. In other countries, for example those presented in this volume, either Ukrainian migration had a longstanding or historical relevance (Poland in Chap. 7, or the Czech Republic in Chap. 8 for example) or the recent flows never constituted such a large contingent in the destination country (Greece in Chap. 9, Spain in Chap. 12 or Italy in Chap. 10). In many of the destination countries of Ukrainian migration, women migrants are significantly in the majority (for example in Italy and Greece). This has generated important research relating to particular patterns of migrants' incorporation in the labour market (domestic service and care), transnational motherhood or trafficking. Over time, there has nevertheless been a certain trend towards increased participation of men in migration to, for example, Greece and Italy (see Chaps. 9 and 10). In Portugal, similarly to the Czech Republic, by contrast, migration was initially dominated by men with increasing numbers of women over time (see also Chap. 8).

The original version of this chapter was revised. An erratum to this chapter can be found at DOI 10.1007/978-3-319-41776-9_14

M.L. Fonseca $(\bowtie) \bullet$ S. Pereira

Centre for Geographical Studies, Institute of Geography and Spatial Planning,

Universidade de Lisboa, Lisboa, Portugal

e-mail: fonseca-maria@igot.ulisboa.pt; sonia.pereira@campus.ul.pt 
The core initial mobility (mostly between 2000 and 2002) was closely related to a particularly high labour demand in the construction sector. Soon after this sudden increase, the number of Ukrainians residing legally in the country (without Portuguese citizenship) dropped significantly. Between 2004 and 2007 (due to both return and onward migration to other European countries, even though the respective numbers are difficult to quantify), the number of Ukrainians fell from 66,281 (2004) to 39,480 (2007). ${ }^{1}$ The number registered an increase again between 2007 and 2009 (52,293 registered by SEF - Aliens and Border Service) and was followed by a new decline (in 2013: 41,091 and in 2014: 37,852). Despite the recent political instability in Ukraine the effects of the economic crisis in Portugal, which particularly affected the construction sector, seem to have had an even greater impact in terms of halting the flow from Ukraine to the country (see Fonseca et al. 2016 on the role of negative feedback in Ukrainian migration to Portugal). Since 2004 new arrivals have been mostly due to family reunifications, resulting in an increasing share of women within the Ukrainian group. More recently an increasing number of Ukrainians have acquired Portuguese citizenship (4,336 in 2013).

This chapter provides an overview of the main features of Ukrainian migration to Portugal, drawing on literature review, analysis of secondary data and original data gathered through exploratory interviews with key informants, i.e. semi-structured interviews with 32 Ukrainians residing in the Lisbon Metropolitan Area in 2011 and a survey of 306 Ukrainians in the same area conducted by questionnaire in 2012 for the THEMIS project ${ }^{2}$ (for more details on the survey see Horgen Friberg and Horst 2014; Kubal et al. 2014). In addition, gaps in existing research are considered and recommendations provided for a future research agenda. The chapter starts by presenting the state of the art in the relevant research and moves on to the analysis of empirical data. First, the volume and dynamics of the migratory movement over time are examined. Second, migrants' socio-demographic profiles are presented. Third, the spatial dynamics of the migration are identified by looking at the regions of origin and destination. Fourth, patterns of settlement at destination are examined by considering legal status, labour market incorporation, social interactions, overall migration objectives and evaluation of migration outcomes. Fifth, transnational relationships with Ukraine are analyzed. The chapter concludes with suggestions for future research agendas.

\footnotetext{
${ }^{1}$ Data from Aliens and Borders Service (SEF): http://sefstat.sef.pt/.

${ }^{2}$ Research Project - Theorising the Evolution of European Migration Systems. Financial support for THEMIS from the NORFACE research programme on Migration in Europe - Social, Economic, Cultural and Policy Dynamics is acknowledged.
} 


\subsection{State of the Art: Research on Ukrainian Migration to Portugal}

Studies and subsequent publications about Ukrainian migration to Portugal are as recent as the migration to the country and reflect two principal concerns that were generated by the features of the population movement mentioned above. They aim, first to understand how it was constituted so suddenly and the role of organized smugglers/traffickers in the process, and second to identify how Ukrainians are integrating in the country. This migration gradually began around the end of the 1990s, peaking in the early 2000s (2000 and 2001 in particular), and the first studies began to appear shortly thereafter. Most were empirical in nature and were intending to provide policy input more than contributing to improved theorization in migration studies.

The first comprehensive and large-scale study of Eastern European migration (mostly from Ukraine but also including other Eastern European countries: Russia, Moldova and Romania) was carried out in Portugal first in 2002 and then a followup in 2004 by Baganha et al. (2004, 2010). These studies offer a global overview of the main characteristics of the migratory movement, the trajectories of the migrants, their demographic and socio-economic profiles and also the patterns of their settlement in the country, including incorporation in the labour market, language fluency, civic participation and perception of discrimination felt in Portugal. A particular emphasis in these studies was on the conditions facilitating this unexpected new migration.

Following more of a theoretical concern, this topic has also more recently been studied by Fonseca et al. (2014), who pay particular attention to the role of organizations (including criminal organizations), social networks and feedback mechanisms in the constitution of such an intense and sudden flow, by drawing on the data collected for the THEMIS project mentioned above.

Another study that focused on a different feature of this migration was conducted and published by Fonseca et al. (2004) who explore the geographical dispersal of Ukrainians within the national territory. While previous migrants, largely from former Portuguese colonies in Africa, had mostly been concentrated in the Lisbon Metropolitan Area, Ukrainian immigrants settled all over the country, even in territories that had experienced very little immigration before. This was observed for example in the district of Évora, in the southern region of Alentejo, to which Ukrainian immigrants were drawn by opportunities in the local labour market. Unlike other migrant groups with a longer-standing presence in the country, Ukrainians had no significant social networks in particular regions. This absence of previous links facilitated their territorial dispersal. The authors also present a description of the demographic and socio-economic profile of the immigrants as well as the patterns of their settlement and migration trajectories. Overall, apart from its empirical findings, this study also feeds into an under-researched topic in migration studies: migration into rural areas. 
Focusing on migrant trafficking, Peixoto et al. (2005) present yet another specific dimension of Eastern European (including Ukrainian) migration to Portugal, based on interviews and analysis of court cases related to trafficking for both labour and sexual exploitation as well assistance in illegal migration. In the same research the authors also examine Brazilian immigration which registered an important growth roughly at the same time as Eastern European migration. This study intended to theorize the links between migratory movements and a continuum of possible forms of "organized" migration from simple smugglers to organized criminal groups that not only organize migration but continue to operate through extortion once the migrants have found employment. In addition, by drawing on information available through the files of court cases in Portugal this research is original both in the methodology used and in the empirical data collected.

In a book published the same year, Ferreira et al. (2005) provide a more macrostructural analysis of the new Eastern European flow to Portugal and elsewhere in Europe, which also includes a characterization of trajectories and migrant profiles. This research presents a more structuralist view of how migrations are shaped by larger macro-economic contexts.

In the initial important publications regarding Ukrainian migration to Portugal referred to above, it is noteworthy that Ukrainian migration is never considered individually but always as part of a larger Eastern European group which arrived more or less at the same time and which shared common migration dynamics. The Ukrainians constituted, nonetheless and from the outset, the largest national group, by far, within this Eastern European contingent. However, since those early years of Eastern European migration to Portugal, when Russians, Romanians and Moldovans constituted a much smaller share (Baganha et al. 2010: 14), the number of Romanian immigrants in the country has registered a strong increase (from 10,938 in 2002 (Baganha et al. 2010: 16) to 34,204 in 2013, according to data from SEF). However, there are still few studies exploring the specific characteristics of this migration flow to Portugal.

Subsequent studies (examples below) aimed at expanding the understanding of the settlement patterns of Ukrainian immigrants in Portugal by looking at work, housing, legal status, education, access to health care and religion, within the realm of a conceptual framework of integration. The integration of Ukrainian immigrants in Portugal was approached both globally, at the national level, and in specific local and socio-professional contexts (the health-care sector in particular) where empirical data on the basic features of the phenomenon were missing. This approach was mostly a response to policy concerns by Portuguese institutions that had to react to the presence of large numbers of immigrants previously unknown in the country and who were ill prepared in terms of language skills and knowledge of prevailing norms, including both accessing rights and fulfilling obligations. In addition, widespread instances of immigrant exploitation and abuse both by those who had organized the migration (from Ukraine as well as nearby countries) and by less scrupulous employers (for more details on the exploitative situations faced by Eastern European immigrants, see for example Pereira and Vasconcelos 2008) generated the need for an institutional response and thus for empirical evidence to 
support it. Studies include both those that focused specifically on Ukrainian migration or on Eastern European population movements more generally, and those that incorporate Ukrainian migration as part of larger studies of immigration in Portugal (some examples are Sousa 2006, Oliveira 2005, Hellerman 2005, Miranda 2009 and Pereira 2010). Three of the more generalist studies developed in the mid-2000s stand out as more significant in their inclusion of Ukrainian immigration. Wall et al. (2005) look at the specific trajectories of migrant women, including Ukrainians among other nationalities, which highlights the diversity of trajectories of migrant women and identifies the main problems they face. In the case of Ukrainian women the authors identify loneliness, lack of language skills, housing, working conditions, the legalization process, family reunification and issues with their children, discrimination and cultural shocks. Fonseca et al. (2005) and Fonseca and Ormond (2008) focus on family reunification processes. Carneiro et al. (2006) examine labour market trajectories of immigrants in Portugal, highlighting the different sectors and occupations where migrants find employment and the specificity of Ukrainian presence in agriculture and industry. The authors also identify a U-shaped trajectory with initial downgrade and progressive improvements with time of stay even though the time period considered for this evaluation is very limited.

\subsection{Migration from Ukraine to Portugal: Analysis of Empirical Data}

This section uses data gathered and published in previous studies: the two nationwide surveys of 2002 and 2004 by Maria Ioannis Baganha and her team; and the studies conducted by the Centre for Geographical Studies with Eastern European migrants in the Alentejo region (Fonseca et al. 2004 and Fonseca 2008) and nationwide about processes of family reunification (Fonseca et al. 2005 and Fonseca and Ormond 2008). In addition, 2011 census data and original data gathered for the THEMIS project and only partially published in Fonseca et al. (2014) are used. These data are the most comprehensive collected in the country in terms of both geographical coverage and survey dimensions. In addition, the data provide a time frame that ranges from initial stages of arrival in Portugal to more recent years, including the effects of the economic crisis Portugal has been experiencing since the end of 2008.

In the THEMIS project, the Ukrainian immigrants interviewed were selected through a snowball sampling strategy and in the case of the survey a sample was selected using the respondent-driven sampling (RDS) method (more details in Horgen Friberg and Horst 2014 and Kubal et al. 2014). There is a slight predominance of men over women among the respondents $(52.9 \%$ and $47.1 \%$ of the total, respectively), and there are no significant deviations in terms of the proportion of men and women indicated by the RDS estimator $(53.1 \%$ for the men and $46.9 \%$ for the women). It must also be noted that the proportion of men and women indicated 
in the 2011 population census is very similar to the figures obtained by the RDS estimator. The sample is therefore sufficiently robust and diverse to offer a reliable portrait of Ukrainian immigrants residing in the Lisbon Metropolitan Area.

\subsubsection{Volume and Dynamics of Migration Over Time}

Since 2001 Ukrainians have ranked among the largest foreign-national groups in Portugal; between 2008 and 2012 they maintained a stable second position in the ranking of foreign nationals that reside legally in Portugal and in 2013 they fell to third position, after Brazil and Cape Verde, a position that was maintained in 2014 (data from SEF). The number of Ukrainian nationals grew until 2004, registered a decline until 2007 and recovered in 2008 and 2009. The numbers have been declining since then (from 52,293 in 2009 to 41,091 in 2013). Interestingly, the number of Romanian immigrants grew between 2008 and 2011 (from 27,769 to 39,312) and only began to decline thereafter, falling to 34,204 in 2013 (data from SEF). Immigration from Poland has not reached the same levels in Portugal as observed elsewhere (only 1,238 registered by SEF in 2013).

Around 2004 a large number of Ukrainians began to leave the country (the number of registered legal residents dropped from 66,281 in 2004 to 39,480 in 2007), either to return to their country of origin or to migrate further to other European countries (taking advantage of labour market opportunities, for example in construction in Spain). However, little is actually known about the exit patterns of Ukrainians who left Portugal at that time. One interview with the representative of a Ukrainian association in Portugal indicated that Ukrainians who had gone to Spain to take advantage of labour market opportunities and also of higher wages returned to Portugal when the crisis began to affect Spain and also because, in spite of the higher wages in Spain, Ukrainians prefer the greater stability they enjoyed in Portugal in other ways, such as the immigration regime and conviviality. However, this is only episodic evidence and further research would be needed to better understand the internal circulation of Ukrainian migrants in Europe.

In more recent years most of the arrivals have been due to family reunifications, with a falling labour market demand, particularly in the construction sector. Accurate numbers are difficult to obtain because even when family reunification is the primary reason, other types of permit - for example for employment or study purposes - may be used. As documented elsewhere (Fonseca et al. 2004: 6), the THEMIS data has shown that with time there has been increasing participation of women in the migratory movements from Ukraine and the motives "joining family members and other persons you care about" and "studying" have become more important than "work" motives, which most likely indicates the relevance of family reunification processes. Those that arrived between 1998 and 2003 were mostly male $(57.6 \%)$ and driven by work-related motives (77.1\%). By contrast, arrivals between 2009 and 2011 included 58.3\% women, and "being with family members or other people you care about" was the most important motive indicated for 
migration (52.1\%) (For a discussion on the implications of gendered employment sectors see Chap. 5.) Overall, migration is currently declining and its future rate is uncertain in view of the current low demand in the labour market in Portugal that has followed the effects of the international financial crisis of 2008 and the intervention of the Troika (International Monetary Fund, European Central Bank and European Commission) through an austerity plan. However, there are some signs of a tendency towards circular migration on the one hand, and permanence in Portugal on the other. The THEMIS survey (conducted in 2012) indicates that $28.5 \%$ of Ukrainians interviewed wanted to spend part of their time in Ukraine and part in Portugal, $28.5 \%$ would like to remain in Portugal, $22.3 \%$ would prefer to return to Ukraine and $16.5 \%$ aspired to re-emigrate to another country (4.2\% did not know or did not respond). In addition, the political events that took place in Ukraine in late 2013 and throughout 2014, including violent clashes, are likely to affect the migratory pressure with unknown consequences for further flows to destination countries where other Ukrainians have already settled.

\subsubsection{Migrants'Socio-demographic Profiles}

The flow of immigrants was at first by and large labour-market oriented and dominated by male adults, with an increasing number of women arriving in subsequent years. According to data from the population census, men represented $50.8 \%$ of the Ukrainian population residing in Portugal in 2011, falling from $81.4 \%$ in 2001. This reflects processes of return to Ukraine but also of remigration to other European countries where labour market opportunities are better, especially for men who found themselves unemployed due to the crisis in the construction sector. According to census data, in 2011 Ukrainian women who had still been resident in Ukraine in 2005 made up $60.1 \%$ of the total, which is illustrative of more recent migration of Ukrainian women to Portugal. In the survey conducted in 2002 by Baganha et al. (2010: 33) nearly $71 \%$ of Ukrainians residing in the country at that time were men. The same survey also reveals that, at that time, nearly $42 \%$ of the spouses and $60 \%$ of the children lived in Ukraine (as opposed to 30\% and 9\% in Portugal, respectively) (Baganha et al. 2010: 36).

Concerning age profiles, Baganha et al. (2004) indicate that the average age of the sample surveyed was 36 years old and indeed, data from SEF for 2006 reveal that around $69 \%$ of legal residents of this origin were aged 30 or older with the highest concentration in the 30-34 age group (18\%) followed by 35-39 (15\%). In 2011, the average age of the Ukrainian population was 34 (census data), that is 8.1 years younger than the Portuguese population. The average education level of these immigrants is high in comparison with both the Portuguese population and other thirdcountry nationals. In the sample surveyed by Baganha et al. (2005: 38) 69\% had completed secondary education or equivalent vocational training and $31 \%$ had tertiary education. The 2011 census indicates similarly high educational levels: secondary and post-secondary school levels were the most frequently found education 
levels among Ukrainian nationals, reaching 46.82\%, whereas only $19.9 \%$ of the national population were educated to these levels. Moreover, $23.3 \%$ of the Ukrainian population in the active age bracket (15-64 years) had completed higher education, $46.82 \%$ held a secondary or post-secondary school diploma, $20.26 \%$ had completed the third level of basic schooling and only $9.68 \%$ had an education level lower than this.

\subsubsection{Spatial Dynamics: Regions of Origin and Destination}

Earlier studies of Ukrainian migration to Portugal have identified the western part of Ukraine as the most important sending region, particularly the oblasts of Lviv, Ternopil, Khmelnytskyi, Ivano-Frankivski and Chernivts (Baganha et al. 2010: 38). Other important sending regions identified by the same authors were Kyiv, Cherkasy and Donetsk. The THEMIS survey obtained similar findings and was also able to capture the existence of migration from Luhansk Oblast (sending region for close to $3 \%$ of the total), which the previous study did not find. Despite the widespread representation of Western Ukraine as the sending region, there is also a remarkable dispersion of sending areas, including Eastern Ukraine (Donetsk Oblast was the region of origin for around $11 \%$ of Ukrainians according to the THEMIS survey). According to Baganha et al. (2010: 40), the majority of Ukrainian immigrants originated from urban areas $(69 \%)$ but migrants from rural areas were also significantly represented (29.4\%). For more on Ukrainian migrants' regions of origin, see Chap. 7. The THEMIS survey has also been able to capture the previous international trajectories of Ukrainians who moved to Portugal. Around $28 \%$ had lived in another country before moving to Portugal, mostly in Russia (29), Poland (20), Germany (16) and the Czech Republic (10). These have all been longstanding destinations of Ukrainian migration and therefore it is unsurprising that prior migration experiences had taken place there.

In Portugal, Ukrainian immigrants have settled all over the country, especially in the early days of the inflow, but with higher concentration levels in the districts of Faro, in the Algarve (around 20\% in 2005), Lisbon (around 20\% in 2005), Santarém (around 12\% in 2005) and Leiria (around 10\% in 2005) (SEF). However, with time, we can observe some changing patterns of geographical concentration. There is an increasing concentration in Lisbon (data from SEF record around 26\% in this district in 2009 and 28\% in 2013), a decrease in Santarém (7\% in 2009; stable in 2013) and also a slight decrease in Faro (to 18\% in 2013). In the THEMIS survey, $15 \%$ of Ukrainians living in the Lisbon Metropolitan Area had initially arrived elsewhere in the country. Upon arrival, the majority of Ukrainians interviewed (86\%) either stayed with someone who already had a house or received help to find initial accommodation.

Census data for processes of geographical mobility of Ukrainians in the period 2005-2011 also provide evidence of some, mostly short-distance, spatial mobility: $36.8 \%$ remained in the same place, $33.8 \%$ moved to another location within the 
same municipality, $10.3 \%$ lived in a different municipality in 2005 and $14.9 \%$ resided abroad. It is worth noticing that the proportion of women who resided abroad in 2005 is higher than that of the men (18.2\% and $11.7 \%$, respectively), confirming the trend towards the feminization of more recent migrations resulting from family reunification processes.

\subsubsection{Migration Process and Patterns of Settlement at Destination}

Various studies have shown that most Ukrainians first entered the country on Schengen tourist visas and remained irregularly until they obtained their first permit to stay legally. For example, the THEMIS survey shows that $96 \%$ had obtained a short-term visa before travelling. A considerable number of these migrants benefited from the change in immigration law in 2001. Following the entry into force of the new legislation, irregular immigrants were able to obtain a permanence permit by presenting a contract of employment validated by the labour inspection authorities. This permanence permit needed to be renewed every year for 5 years as long as the immigrant presented a valid employment contract, after which they would gain access to a residence permit. In 2004, 64,730 Ukrainians out of a total of 66,281 legal residents had obtained a permanence permit. THEMIS data indicate that after arriving on a short-term visa, nearly $44 \%$ obtained a permit based on their employment and nearly $37 \%$ a permit based on family ties. Despite successive regularization campaigns (see also Chap. 4), there are still a number of Ukrainian immigrants who are undocumented or in the process of regularization. Our research for the THEMIS project indicated that $4.5 \%$ of Ukrainians surveyed did not have any permit to stay in Portugal and nearly $2 \%$ had applied for a permit but had not yet obtained it at the time of the interview (there are ongoing opportunities for regularization in the Portuguese immigration regime).

Ukrainians initially found jobs mostly in construction, industry and agriculture, generally in unskilled occupations, despite their medium-high qualifications (Baganha et al. 2004: 34; Santana and Serranito 2005). In time, a number of them were able to obtain jobs more in line with their qualifications. One such example was a programme to enable medical doctors to obtain recognition of their competencies which ran in 2002 (109 Eastern European doctors completed the course successfully) and again in 2008, sponsored by the Calouste Gulbenkian Foundation. The THEMIS survey shows that at the time of the interview almost $72 \%$ of respondents did not have the same occupation they had had upon arrival. These data show that over the years an important proportion (close to 20\%) have become small employers or independent workers. This evidence matches the information gathered in the semi-structured interviews. For example, one leader of a Ukrainian association mentioned that Ukrainians are increasingly investing in small businesses in Portugal to overcome situations of exploitation in the labour market: retailing of 
Ukrainian products, cafés, restaurants, car repairs, cleaning, construction and sewing services are typical small businesses.

Despite this, in 2011, and according to the population census, the low-skilled and low-paid jobs were still predominant: $33.2 \%$ of Ukrainian men with a job worked in activities related to civil construction, $14.4 \%$ were drivers or mobile equipment operators and $12.5 \%$ were unskilled workers in extractive industries and manufacturing. Among Ukrainian women, the most frequent jobs were cleaning services in private dwellings, hotels and offices (37.2\%), cooks and waitresses (10.3\%), sales assistants (9.6\%) and unskilled workers in manufacturing (6.6\%).

At the higher end of the occupational hierarchy the presence of Ukrainian citizens is minimal. The more skilled and most socially prestigious activities, such as academics and scientists, directors and managers, and intermediate-level technical staff only represented $3 \%, 1 \%$ and $2.5 \%$ respectively of the total employed population of Ukrainian nationality.

Income from work was, according to data from the 2011 population census, the main source of funds for $71 \%$ of the Ukrainian population aged 15 or above. Almost $15 \%$ lived on family means and $7.8 \%$ on unemployment benefit; of the remaining population, $0.68 \%$ received a retirement pension, $1.5 \%$ received other social benefits and $4.1 \%$ had other non-differentiated sources of income.

Regarding Ukrainians' interactions with others from the same origin in Portugal, the THEMIS survey reveals that the vast majority spend their free time with other Ukrainians (around 76\%) while $14.4 \%$ indicate that they cannot identify one "dominant group". They also tend to reside in neighbourhoods with a high concentration of Ukrainians ${ }^{3}$ (close to 59\%) or with at least some Ukrainians (around 36\%), even though they mention that this concentration (or lack thereof) by and large makes no difference to them (around 62\%). Interestingly, similar concentrations of Ukrainians are not found in the workplace. Nearly $22 \%$ work on their own, $21 \%$ work with no other Ukrainians and almost $20 \%$ work with only some Ukrainians. Ukrainians' engagement with Ukrainian organizations or events is mostly restricted to involvement in religious organizations/church (64\% mentioned they go to these at least once in a while). To a lesser extent, Ukrainians in Lisbon also go to events organized by the Ukrainian embassy (close to $30 \%$ ), attend community organizations (23\%) or go to Ukrainian restaurants (around $18 \%){ }^{4}$

Most immigrants interviewed for different research projects showed that theirs was largely a work-driven migration with mostly a short-to-medium-term stay in Portugal in mind, very much rooted in the intention of sending remittances back to Ukraine. Data from the THEMIS survey indicates that nearly $64 \%$ had "job opportunities" as their main motivation to migrate to Portugal and 51\% gave "earning money to send back to Ukraine" as their main reason for leaving Ukraine. Since the initial stages of Ukrainian migration, researchers have observed that, on arrival in Portugal, most Ukrainian immigrants' migration projects are short-term ones. According to a national survey conducted in December 2004 and January 2005

${ }^{3}$ Corresponds to the answer option "there's a lot of people from Ukraine" in the neighbourhood.

${ }^{4}$ THEMIS data. 
(Fonseca et al. 2005) and another one conducted in the Alentejo region in April 2003 (Fonseca et al. 2004), more than $70 \%$ of Ukrainian migrants claimed that they intended to stay in Portugal for less than 6 years. Moreover, it is important to stress that in the survey conducted in Alentejo, approximately $20 \%$ of the respondents said they intended to re-emigrate to another European country or the USA, and approximately $12 \%$ said they intended to stay permanently in Portugal. In the THEMIS survey, 35\% indicated that when they moved to Portugal their intention was to stay 1 year or less and a little over $37 \%$ claimed they intended to stay between 1 and 5 years. The same survey also confirms the trend towards onward migration from Portugal: $85.4 \%$ of respondents know immigrants who have returned to Ukraine or have re-emigrated to another country.

Ukrainians' overall evaluation of the benefits of migration to Portugal is positive, according to THEMIS data. For nearly $51 \%$ their economic situation is somewhat better today as a result of moving, compared with what it would have been if they had stayed in Ukraine, and for $22 \%$ it is much better. The evaluation is even better if quality of life apart from economic issues is considered. In this case, $34.6 \%$ considered that it is much better today and $42.8 \%$ that it is somewhat better. The same data indicate that most Ukrainians perceive Portugal as a country where immigration policies are not very strict $(76.5 \%)$, and where men and women from Ukraine are seen in a positive way (75.8\% and $88.2 \%$, respectively). However, regarding the economic opportunities available in Portugal, opinions are more mixed: $41.5 \%$ consider that there are good economic opportunities and $49.3 \%$ disagree with that statement.

\subsubsection{Transnational Contacts and Practices}

Transnational links with the country of origin are generally maintained through regular communication, travel and remittances. The THEMIS survey indicates that the majority of Ukrainians have visited Ukraine at least once (only $17.3 \%$ have not). In addition, the same data show that close to $73 \%$ have gone back to Ukraine for a visit more than once. Communication (by any means) with people back in Ukraine is also regular: $85.3 \%$ communicate either almost every day $(31.7 \%)$ or every week $(53.6 \%)$. In the month preceding the interview most of them had communicated with close family members - mother (148), sister (92), daughter (87), son (84) - and friends, colleagues or classmates - male (125), female (95).

As far as remittances are concerned, Fonseca et al. (2005) observed a strong relation between the level of remittances sent home and the presence of partners and dependent children living in the country of origin. Specifically, among Ukrainian respondents, the proportion of those sending remittances more regularly (the last remittance had been sent less than a year ago) was more than $90 \%$ among those having dependent children and/or partner/spouse in Ukraine. However, even if there were no such links to Ukraine, more than $60 \%$ declared they sent remittances regularly. More recent research indicates that sending remittances to Ukraine is still very 
important. For example, according to the results of the THEMIS survey, $50 \%$ of the respondents said that they send remittances to Ukraine on a regular basis, while only $13.6 \%$ stated that they have never sent any remittances home. The same data also indicate that investments made in the origin country mostly involved housing $(23.5 \%)$ or sending money to support a religious organization $(11.4 \%)$.

\subsection{Conclusions}

Ukrainian migration to Portugal took place mostly between the late 1990s and early 2000s. Initially, it was largely male migration with work objectives and short-term migration projects. This process was enabled by a major demand for labour in the construction sector at that time, due to large public works being carried out in the country. The work of people smugglers and traffickers, and social networks established and perpetuated this migratory movement. The lack of previous links in the country facilitated geographical dispersal throughout the territory. Overall, this was a unique immigration experience for Portugal, where previous significant migration had originated in former colonies with historical connections to the country, shared language and social networks that generated large immigrant settlements in the Lisbon Metropolitan Area and smaller concentrations elsewhere (in the Algarve for example).

Over time, there has been an increasing participation of Ukrainian women, associated largely with processes of family reunification, and short-stay projects have turned into medium-to-long-term settlement. Nevertheless, after 2004 Ukrainians both returned to Ukraine and moved on to other European countries with more attractive labour market opportunities. Initially, entry was largely irregular, with tourist visas for Schengen followed by a period of irregularity until a permit was obtained. Portuguese immigration legislation has allowed irregular immigrants the opportunity of obtaining a valid permit to reside in the country if they can prove their participation in the labour market through contracts and respective social security payments. More research is needed on Ukrainians' onward migration strategies within Europe, on the one hand, and return practices and potential circular migration, on the other. Another topic requiring more in-depth research is the transnational practices adopted by Ukrainian nationals who have settled in Portugal more permanently towards both Ukraine and other destinations of Ukrainian migration.

As regards their settlement patterns in Portugal, continuity with the research that began in the early years of Ukrainian migration to the country is important, so that the dynamics of their prolonged stay, the effects on them of the post- 2008 economic crisis and the resulting strategies they have developed can be captured. It is nonetheless interesting to note: (1) how overwhelmingly short-to-medium-term plans have turned into more permanent settlement for at least a proportion of Ukrainian immigrants; and (2) that their evaluation of the effects of migration on their life trajectories is mostly positive, even though they have experienced de-skilling in the labour market (despite some upward mobility that has also taken place with time) and their 
perception of economic opportunities in Portugal is more negative than positive. At the same time, one should not forget how many have acquired Portuguese nationality and the influence this will have on their future plans to remain in Portugal or migrate elsewhere in Europe. Given the new socio-political context in Ukraine and the enduring crisis in Portugal this is certainly an immigrant group that requires further research not only at the national level but also within Europe as a whole.

\section{References}

Baganha, M. I., \& Fonseca, M. L. (Eds.). (2004). New waves: Migration from Eastern to Southern Europe. Lisbon: Luso American Foundation.

Baganha, M. I., Marques, J. C., \& Góis, P. (2004). The unforeseen wave: Migration from Eastern Europe to Portugal. In M. I. Baganha \& M. L. Fonseca (Eds.), New waves: Migration from Eastern to Southern Europe (pp. 23-40). Lisbon: Luso American Foundation.

Baganha, M. I., Marques, J. C., \& Góis, P. (2005). Imigrantes de Leste em Portugal [Eastern European Immigrants in Portugal]. Revista de Estudos Demográficos, 38, 31-45.

Baganha M. I., Marques J. C., \& Góis P. (Eds.). (2010). Imigração ucraniana em Portugal e no Sul da Europa: a emergência de uma ou várias comunidades? [Ukrainian immigration in Portugal and Southern Europe: The emergence of one or several communities?]. Lisbon: Alto Comissariado para a Imigração e o Diálogo Intercultural (ACIDI, I.P.).

Carneiro, R., A. C. d. Almeida, et al. (2006). A mobilidade ocupacional do trabalhador migrante em Portugal [Occupational mobility of the migrant worker in Portugal], Direcção-Geral de Estudos Estatística e Planeamento (DGEEP).

Ferreira, E. S., Rato, H., \& Mortágua, M. J. (2005). Novos Caminhos da Europa: A Imigração de Leste [Europe's new paths: Eastern European immigration]. Oeiras: Celta Editora.

Fonseca, M. L. (2008). New waves: Immigration to small towns and rural areas in Portugal. The case of Alentejo region. Population, Space and Place, 14(6), 525-535.

Fonseca, M. L., \& Ormond, M. (2008). Defining 'Family' and bringing it together: The ins and outs of family reunification in Portugal. In Ralph Grillo (Ed.), The family in question immigrant and ethnic minorities in multicultural Europe, IMISCOE-AUP: 89-111.

Fonseca, M. L., Alegria, J., \& Nunes, A. (2004). Immigration to medium sized cities and rural areas: The case of Eastern Europeans in the Évora Region (Southern Portugal). In M. I. Baganha \& M. L. Fonseca (Eds.), New waves: Migration from Eastern to Southern Europe (pp. 91-118). Lisbon: Luso-American Foundation.

Fonseca, M. L., Ormond, M., Malheiros, J., Patrício, M., \& Martins, F. (2005). Reunificação Familiar e Imigração em Portugal [Family reunification and immigration in Portugal]. Lisbon: Alto Comissariado para a Imigração e Minorias Étnicas (ACIME).

Fonseca, M. L., Pereira, S., \& Esteves, A. (2014). Migration of Ukrainian Nationals to Portugal: Changing flows and the critical role of social networks. Central and Eastern European Migration Review, 3(1), 115-131.

Fonseca, M. L., Esteves, A., \& McGarrigle, J. (2016). The economic crisis as feedback-generating mechanism? Brazilian and Ukrainian migration to Portugal. In O. Bakewell, G. Engbersen, M. L. Fonseca, \& C. Horst (Eds.), Beyond networks: Feedback in international migration. Basingstoke: Palgrave MacMillan.

Heckathorn, D. D. (2007). Extensions of respondent-driven sampling. Analyzing continuous variables and controlling for differential recruitment. Sociological Methodology, 37(1), 151-207.

Hellerman, C. (2005). Migração de Leste: mulheres 'sozinhas'. In S. Racismo (Ed.), Imigração e Etnicidade. Vivência e Trajectórias de Mulheres em Portuga (pp. 223-234). Lisbon: SOS Racismo. 
Horgen Friberg, J., \& Horst, C. (2014). Respondent driven sampling and the structure of migrant populations. In G. Tyldum \& L. Rodriguez (Eds.), Applying respondent driven sampling to migrant populations: Lessons from the field (pp. 17-26). Basingstoke: Palgrave Macmillan. [Online] Available at: http://www.palgraveconnect.com/pc/doifinder/10.1057/9781137363619

Kubal A., Shvab I., \& Wojtynska A. (2014). Seeds and setting up the study. In G. Tyldum \& L. Rodriguez (Eds.), Applying respondent driven sampling to migrant populations: Lessons from the field (pp. 37-48). Basingstoke: Palgrave Macmillan. [Online] Available at: http:// www.palgraveconnect.com/pc/doifinder/10.1057/9781137363619.

Miranda, J. (2009). Mulheres Imigrantes em Portugal: Memórias, Dificuldades de Integração e Projectos de Vida [Immigrant women in Portugal: memories, integration difficulties and life projects] OI 35. Lisbon: ACIDI.

Oliveira, M. P. (2005). Percursos Migratórios e Integração Social - Os Ucranianos no Concelho de Leiria [Migration trajectories and social integration - Ukrainians in the municipality of Leiria]. Master's dissertation, Universidade Aberta, Lisboa.

Peixoto, J., Soares, A. G., et al. (2005). O Tráfico de Migrantes em Portugal: Perspectivas Sociológicas, Jurídicas e Políticas [Migrant trafficking in Portugal: Sociological, juridical and political perspectives]. Lisbon: ACIME.

Pereira, S. (2010). Trabalhadores de Origem Africana em Portugal: o Impacto das Novas Vagas de Imigração [Workers of African origin in Portugal: The impact of new migration waves]. Lisbon: Colibri.

Pereira, S., \& Vasconcelos, J. (2008). Human trafficking and forced labour-Case studies and responses from Portugal. Geneva: ILO.

Santana, V., \& Serranito, P. (2005). Percursos de vida de imigrantes de Leste [Life trajectories of Eastern European migrants]. In Imigração e Etnicidade. Vivência e Trajectórias de Mulheres em Portugal [Immigration and etnicity. Experiences and trajectories of women in Portugal] (pp. 235-250). Lisbon: SOS Racismo.

Sousa, J. E. X. F. (2006). Os Imigrantes Ucranianos em Portugal e os Cuidados de Saúde [Ukrainian immigrants in Portugal and healthcare]. Lisbon: ACIME.

Wall, K., Nunes, C., et al. (2005). Immigrant women in Portugal: Migration trajectories, main problems and policies. Lisbon: European Observatory of Family Policies.

Open Access This chapter is distributed under the terms of the Creative Commons AttributionNoncommercial 2.5 License (http://creativecommons.org/licenses/by-nc/2.5/) which permits any noncommercial use, distribution, and reproduction in any medium, provided the original author(s) and source are credited.

The images or other third party material in this chapter are included in the work's Creative Commons license, unless indicated otherwise in the credit line; if such material is not included in the work's Creative Commons license and the respective action is not permitted by statutory regulation, users will need to obtain permission from the license holder to duplicate, adapt or reproduce the material. 